\title{
A NEW BIOACTIVE THIOPHENOLIC GLYCOSIDE FROM THE LEAF OF MASSULARIA ACUMINATA (G. DON BULLOCK) EX HOYLE (RUBIACEAE)
}

\section{Oriola A. O. ${ }^{1}$, Aladesanmi A. J. ${ }^{1 *}$, Idowu T. O. ${ }^{2}$, Akinkunmi E. O. ${ }^{3}$, Obuotor E. M. ${ }^{4}$ and Ogunsina M. O. ${ }^{5}$}

Departments of Pharmacognosy ${ }^{1}$, Pharmaceutical Chemistry ${ }^{2}$, and Pharmaceutics ${ }^{3}$, Faculty of Pharmacy, Obafemi Awolowo University, Ile-Ife, Nigeria' Department of Biochemistry ${ }^{4}$, Faculty of Science, Obafemi Awolowo University, Ile-Ife, Nigeria' Department of Chemistry ${ }^{5}, 360$ Parkers Building, University of Manitoba, Winnipeg, R3T 2N2, Canada

*E-mail: jaladesa@yahoo.com; jaladesa@oauife.edu.ng;

\begin{abstract}
Background: Massularia acuminata is a small tree or shrub of tropical rainforest. The leaves are used in Nigerian ethno-medicine for the treatment of microbial infections and pharmacological report suggested the leaf extract as possessing antioxidant activity. This study was therefore carried out to determine the most antioxidant and antimicrobial active fraction(s) of Massularia acuminata leaf and the constituent(s) responsible for the activities.

Matherials and Methods: The leaf of Massularia acuminata was investigated for in vitro antioxidant and antimicrobial activities, using a 2,2diphenyl-1-picrylhydrazyl (DPPH) radical scavenging assay and agar dilution method respectively.

Results: The ethyl acetate fraction demonstrated the best activities among the partitioned fractions tested. Bioassay guided purification of the most active ethyl acetate fraction led to isolation of a new thiophenolic glycoside, characterized as 4-(3', $3^{\prime}$-dihydroxy-1-mercaptopropyl)phenyl glycosylpyranoside.

Conclusion: The isolated compound from the leaf of Massularia acuminata demonstrated antioxidant and antimicrobial activities and may be responsible for the activities of leaf extract and its ethyl acetate fraction, hence this may justify its ethnomedicinal use.
\end{abstract}

Key words: Massularia acuminata, antioxidant, antimicrobial, DPPH, agar dilution, thiophenolic glycoside

\section{Introduction}

The use of plants in medicine could be regarded as one of the landmark achievements of man's ability to intuitively tap into nature. Many plants contain curative agents, some of which have been implicated in the management of oxidative stress related degenerative diseases (Halliwell, 2007). An Antioxidant is any substance that delays or prevents oxidative damage to a target molecule (Halliwell and Gutteridge, 2007). Some of the commercially available synthetic antioxidants are butylated hydroxyanisole (BHA), butylated hydroxytoluene (BHT) and propylgallate (PG). In recent times, the benefits of some of these synthetic antioxidants have been in doubts due to their possible carcinogenic and toxic effects. Thus, their use are now restricted by legislation in some developed and developing countries, and are gradually being replaced with plant-based antioxidants which are less toxic, readily available and affordable (Gülçin et al., 2005). Among the identified antioxidants in plants are polyphenols, a group of highly hydroxylated aromatic compounds, most of which are antimicrobials (Turkoglu et al., 2006), and it is believed that plants still possess array of new and/or novel lead compounds of antioxidant and antimicrobial properties.

Massularia acuminata (G. Don) Bullock ex Hoyle is locally known in Southwest Nigeria as "Pako Ijebu". The leaves are used in Nigeria as fish poison and for the cure of mouth infections (Burkill, 1997). Pharmacological investigations suggest that leaf methanolic extract possessed antioxidant activity (Aladesanmi et al., 2007), the stem aqueous extract possessed antimicrobial activity especially against periodontal microbes (Taiwo et al., 1999), and the stem has also been implicated as an oral prophylactic and also reported to play an important role in gingival health (Aderinokun et al., 1999). However, the fraction(s) and constituent(s) responsible for antioxidant and antimicrobial activities in the leaf of M. acuminata have not been determined.

In this paper, we report the antioxidant and antimicrobial properties of $M$. acuminata leaf fractions and isolation of a new bioactive compound from the ethyl acetate leaf fraction.

\section{Experimental \\ Equipments and Chemicals}

The Absorbance measurement was taken on CamSpec M 107 Spectrophotometer, Gallenkamp MPD 350.BM2.5 for melting point determination, an ATR Platinum Diamond 1Refl Spectrophotometer for Infrared Spectroscopy, Bruker TOPSINI.3 Spectrometer for NMR Spectroscopy, with ${ }^{1} \mathrm{H}$ NMR at $300 \mathrm{MHz}$ and ${ }^{13} \mathrm{C}$ NMR at $75 \mathrm{MHz}$, TMS, and a Centroid ESI-Mass Spectrometer for molecular mass determination. Column chromatography (CC) was performed on open column, with silica gel 60 (200-400 mesh, ASTM, 0.040-0.063mm, E.merck, Darmstadt, Germany) and Sephadex LH-20. Thin-Layer Chromatography (TLC) was performed on precoated silica gel (Kieselgel 60) GF254 plates (0.25mm, Merck). A 2,2-diphenyl-1-picrylhydrazyl (DPPH) radical and L-ascorbic acid were purchased from Sigma-Aldrich Co., USA. All solvents used were of analytical grade.

\section{Plant Material}

The leaves of Massularia acuminata were collected at the Shasha Forest Reserve, Area J4, Osun State, Nigeria in October, 2010. The plant was authenticated at the Obafemi Awolowo University Herbarium, Ile-Ife, Nigeria, and Voucher number; IFE 16337 was obtained. The leaves were air dried and milled into powder prior to extraction process.

\section{Extraction}

A $1.5 \mathrm{~kg}$ dried and powdered leaf of M. acuminata was exhaustively extracted with $7.5 \mathrm{~L}$ of $80 \%$ Ethanol by maceration, filtered and concentrated to dryness in vacuo, using a Shimadzu NE 100 rotary evaporator to afford $180 \mathrm{~g}$ ethanolic extract (12\% w/w). 
http://dx.doi.org/10.4314/ajtcam.v11i2.15

\section{Fractionation}

The modified Kupchan method of solvent partitioning (Wagenen et al., 1993) was used for fractionation of the extract. This was done by suspending $170 \mathrm{~g}$ of EtOH extract in $100 \mathrm{ml}$ distilled water, partitioned with gradient solvents $(4 \mathrm{x} 200 \mathrm{ml}$ n-Hexane; 5 x $200 \mathrm{ml}$ EtOAc; 2 x $200 \mathrm{ml} \mathrm{n}-\mathrm{BuOH})$ and concentrated in vacuo to afford $\mathrm{n}-\mathrm{Hexane}(8 \mathrm{~g})$, EtOAc $(22 \mathrm{~g}), \mathrm{n}-\mathrm{BuOH}(100 \mathrm{~g})$ and aqueous (35 g) fractions.

\section{Antioxidant Activity: DPPH Radical Scavenging Assay}

In this method, $1 \mathrm{~mL}$ DPPH solution in methanol $(0.05 \mathrm{mg} / \mathrm{mL})$ was added to $1 \mathrm{~mL}$ sample at different concentrations $(10.00-2.00$ $\mu \mathrm{g} / \mathrm{mL}$ for vitamin C; $100.00-6.25 \mu \mathrm{g} / \mathrm{mL}$ for extract, fractions and isolated compound) (Li et al., 2012; Sanchez-Moreno et al., 1998) . The experiment was carried out in triplicate, and the percentage inhibition of DPPH by each test sample was calculated thus:

$\%$ Inhibition of Sample $=\left[\left\{\mathrm{ABS}_{\mathrm{Control}}-\mathrm{ABS}_{\text {Sample }}\right\} / \mathrm{ABS}_{\mathrm{Control}}\right] * 100$

Where $\mathrm{ABS}_{\text {Control }}=$ Absorbance of negative control

$\mathrm{ABS}_{\text {Sample }}=$ Absorbance of positive control/extract/fraction/compound

The concentration that caused a $50 \%$ inhibition of the $\mathrm{DPPH}$ radical solution by each test sample was taken as the $\mathrm{IC}_{50}$ value, the result was statistically analyzed using an analysis of variance (ANOVA) with GraphPad Prism 3.0.

\section{Antimicrobial Activity}

The determination of Minimum inhibitory concentration (MIC) of extracts, fractions, column bulked fractions and isolated compounds on bacterial and fungal strains was done using agar dilution method (CLSI, 2007) on Mueller Hinton Agar (Oxoid) as described by Aladesanmi et al., (2007). Serial dilutions from stock solutions of extracts and solvent fractions (40 mg/mL), bulked column fractions (4 mg/mL), and isolated compound $(2 \mathrm{mg} / \mathrm{mL})$ were prepared. Acriflavin and Ketoconazole (BDH, UK) were used as positive controls against bacteria and fungi respectively, while negative controls used were $95 \mu \mathrm{L}$ each of $50 \%$ aqueous methanol and Tween 80 (Sigma-Aldrich Co., USA).

\section{Isolation and Identification of Compound}

The most active ethyl acetate fraction (A, $19 \mathrm{~g}$ ) was adsorbed unto silica gel and gradiently eluted in an open column (CC) using solvent systems from n-Hexane (100\%) through EtOAc to $\mathrm{MeOH}(100 \%)$. Eluates were bulked into thirteen sub-fractions (A1 - A13) on the basis of their TLC analysis. The most active A10 sub-fraction (4.766 g) was isocratically eluted on Sephadex LH-20 column using DCM - MeOH (8:2) and eluates were bulked into three sub-fractions $\left(\mathbf{A 1 0}_{\mathbf{1}}-\mathbf{A} \mathbf{A 1 0}_{\mathbf{3}}\right)$ on the basis of their TLC analysis. The most active $\mathbf{A 1 0}$ sub-fraction $(430$ mg) was further purified on silica gel CC and gradiently eluted with DCM - MeOH $(8: 2 ; 1: 1)$ and MeOH (100\%) solvent sytems to afford Compound 1 (15 mg, DCM - MeOH 6:4).

\section{Isolated Compound (1)}

4-(3', 3'-dihydroxy-1-mercaptopropyl) phenyl glucosylpyranoside: (Brown semi-solid)

ESI-MS: Base peak $[\mathrm{M}]^{+}$with chlorine adduct at $\mathrm{m} / \mathrm{z} 399.4$; Sodiated molecular ion $[\mathrm{M}+\mathrm{Na}]^{+} \mathrm{m} / \mathrm{z} 385.2$; molecular ion $[\mathrm{M}]^{+}$at $\mathrm{m} / \mathrm{z} 362$ consistent with a molecular formula $\mathrm{C}_{15} \mathrm{H}_{22} \mathrm{O}_{8} \mathrm{~S}$; loss of $\mathrm{C}_{2} \mathrm{H}_{2} \mathrm{O}_{2}[\mathrm{M}+2]$ at $\mathrm{m} / \mathrm{z} 304.4\left(\mathrm{C}_{13} \mathrm{H}_{20} \mathrm{O}_{6} \mathrm{~S}\right)$;

IR: $(\mathrm{KBr}),\left(v, \mathrm{~cm}^{-1}\right): 3400-3200(\mathrm{OH}), 2954.88$ (Aryl C $\left.-\mathrm{H}\right), 2855.03$ (aliphatic $\left.\mathrm{C}-\mathrm{H}\right), 1725.03(\mathrm{C}=\mathrm{O}$ : of sugar substituted tautomeric phenone), $1269.81(\mathrm{C}-\mathrm{OH}), 1071.17(\mathrm{C}-\mathrm{O}), 742.82(\mathrm{C}-\mathrm{S})$;

${ }^{1}$ H-NMR: $\left(\mathrm{CD}_{3} \mathrm{OD}\right) \delta$ - of aglycone: $2.35\left(2 \mathrm{H}, b d, \mathrm{H}-2^{\prime}\right), 3.23-4.28\left(1 \mathrm{H}, m, \mathrm{H}-1^{\prime}\right), 4.64\left(1 \mathrm{H}, d, J=9.0 \mathrm{~Hz}, \mathrm{H}-3^{\prime}\right), 6.66(1 \mathrm{H}, d d, \mathrm{H}-2, \mathrm{H}-6), 7.49$ $(1 \mathrm{H}, d d, \mathrm{H}-3, \mathrm{H}-5)$; glucose: 3.23-4.28 (1H, $\left.m, \mathrm{H}-2^{\prime \prime}, \mathrm{H}-3^{\prime \prime}, \mathrm{H}-4^{\prime \prime}, \mathrm{H}-5^{\prime \prime}, \mathrm{H}-6^{\prime \prime}\right), 5.67\left(1 \mathrm{H}, d, J=6.0, \mathrm{H}-1^{\prime \prime}\right)$;

${ }^{13}$ C-NMR: $\left(\mathrm{CD}_{3} \mathrm{OD}\right) \delta$ - of aglycone: $35.00\left(\mathrm{C}-1^{\prime}\right), 39.78\left(\mathrm{C}-2^{\prime}\right), 96.44\left(\mathrm{C}-3^{\prime}\right), 115.43(\mathrm{C}-2, \mathrm{C}-6), 131.95$ (C-3, C-5), 142.12 (C-4), $154.67(\mathrm{C}-1)$; glucose: $62.75\left(\mathrm{C}-6^{\prime \prime}\right), 71.23\left(\mathrm{C}-4^{\prime \prime}\right), 74.93\left(\mathrm{C}-3^{\prime \prime}\right), 77.44\left(\mathrm{C}-2^{\prime \prime}\right), 78.17\left(\mathrm{C}-5^{\prime \prime}\right), 100.16\left(\mathrm{C}-1^{\prime \prime}\right)$;

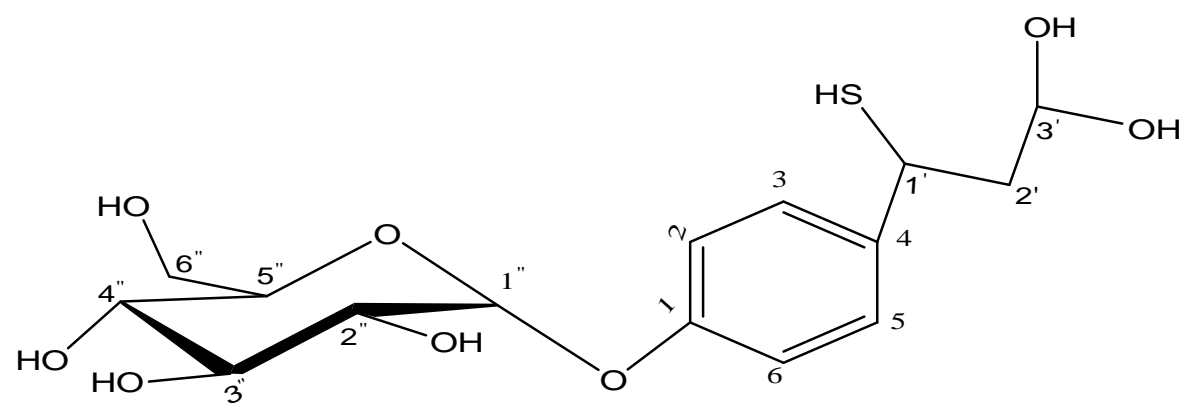

(1)

Figure 1: Structure of Isolated Compound

\section{Results \\ In vitro Antioxidant activity}

The concentration that inhibited $50 \%$ of DPPH radical solution was taken to be the $\mathrm{IC}_{50}$ values for all tested samples. In the figure 2 below, Vitamin $\mathrm{C}$, the standard drug used, demonstrated the lowest $\mathrm{IC}_{50}$ value $(7.59 \pm 0.28 \mu \mathrm{g} / \mathrm{mL})$ and invariably the highest antioxidant activity among all tested samples. However, ethyl acetate fraction demonstrated a significantly $(\mathrm{p}<0.05)$ higher DPPH radical scavenging activity than each of the partitioned fractions tested. Its DPPH radical scavenging activity was also comparable $(\mathrm{p}<0.05)$ to that of the isolated compound $(\mathbf{1})$. Hence, the order of antioxidant activity: Vitamin $\mathrm{C}>$ Ethyl acetate fraction $\geq$ Isolated Compound $>$ Aqueous fraction $>$ n-Butanol Fraction. 
Oriola et al., Afr J Tradit Complement Altern Med. (2014) 11(2):319-323

http://dx.doi.org/10.4314/ajtcam.v11i2.15

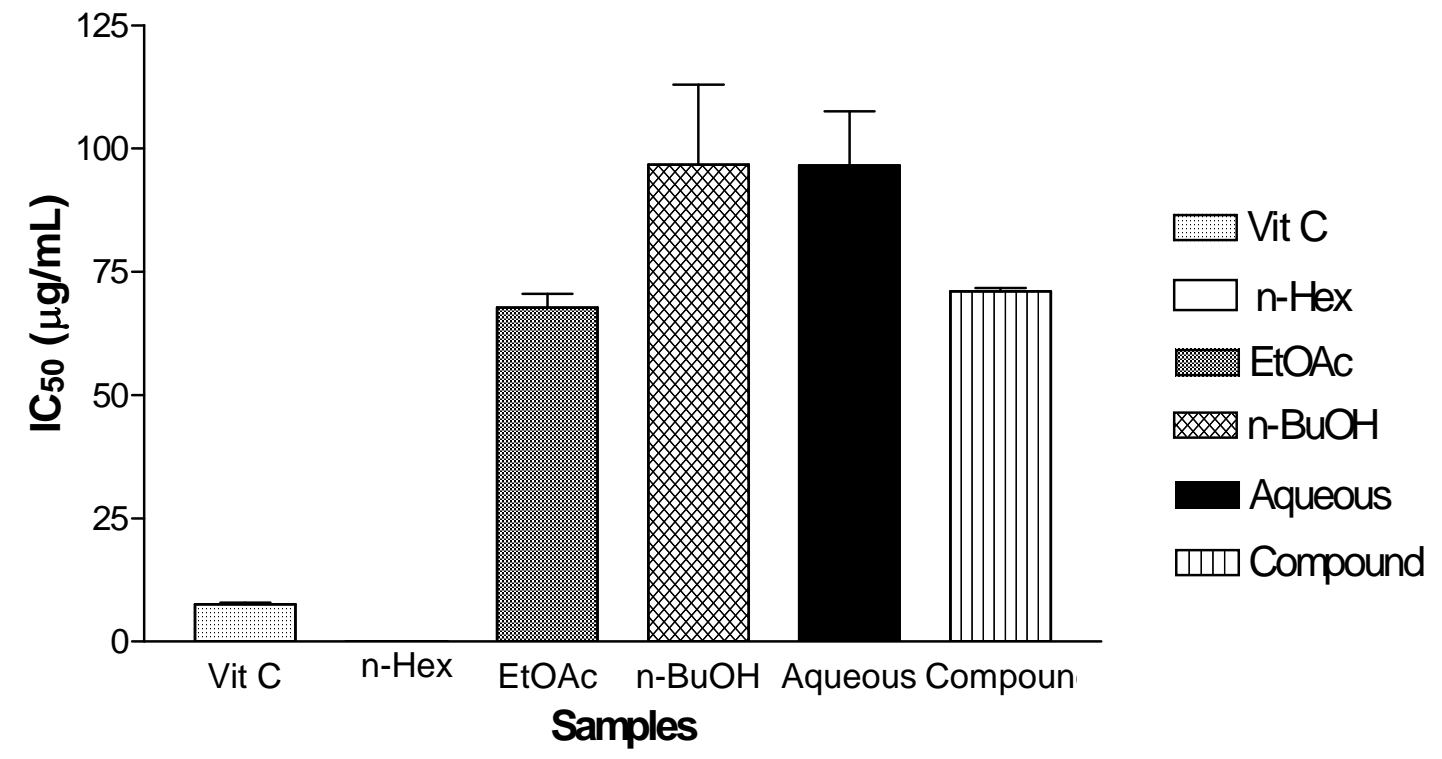

Figure 2: DPPH Free Radical Scavenging Activity of Fractions and Isolated Compound from Ethanolic extract of M. acuminata Leaf

\section{Antimicrobial Activity}

In the Table 1 below, ethyl acetate fraction exhibited the widest spectrum of antimicrobial activity (MIC range: $5-40 \mathrm{mg} / \mathrm{mL}$ ) among the four partitioned fractions tested. Some of the susceptible pathogens were reference strain of methicillin resistant Staphylococcus aureus (Gram-positive bacteria), clinical strain of Clostridium sporogens (Gram-negative bacteria), NCTC strains of Candida albicans and C. pseudotropicalis (fungi). The isolated compound from ethyl acetate fraction demonstrated the widest spectrum of antimicrobial activity (MIC range: $0.25-2.00 \mathrm{mg} / \mathrm{mL}$ ) among the plant samples tested. However, clinical strain of Clostridium sporogens and NCTC strain of Candida pseudotropicalis were susceptible to the isolated compound at MIC of $0.25 \mathrm{mg} / \mathrm{mL}$. Thus, the order of antimicrobial activity: Acriflavin, ketoconazole > Isolated compound > ethyl acetate fraction > ethanolic extract > n-Butanol fraction > Aqueous fraction > n-Hexane fraction > Aq. $\mathrm{MeOH}$, Tween 80.

Table 1: Minimum Inhibitory Concentration (MIC) of M. acuminata extracts

\begin{tabular}{|c|c|c|c|c|c|c|c|c|c|}
\hline \multirow{2}{*}{ SAMPLE } & \multicolumn{9}{|c|}{ MIC of Samples against Tested Microorganisms $(\mathrm{mg} / \mathrm{mL})$} \\
\hline & $\begin{array}{l}\text { E. coli } \\
\text { Clinical }\end{array}$ & $\begin{array}{l}\text { Pseudomonas } \\
\text { aeruginosa } \\
\text { ATCC }\end{array}$ & $\begin{array}{l}\text { Klebsiella } \\
\text { pneumonia } \\
\text { Clinical }\end{array}$ & $\begin{array}{l}\text { Clostridium } \\
\text { sporogens } \\
\text { Clinical }\end{array}$ & $\begin{array}{l}M R S A \\
\text { Reference }\end{array}$ & $\begin{array}{l}\text { Shigella } \\
\text { Clinical }\end{array}$ & $\begin{array}{l}M R S A \\
\text { Clinical }\end{array}$ & $\begin{array}{l}\text { Candida } \\
\text { albicans } \\
\text { NCTC }\end{array}$ & $\begin{array}{l}C . \\
\text { pseudotr } \\
\text { opicalis } \\
\text { NCTC }\end{array}$ \\
\hline n-Hexane & $>40$ & $>40$ & $>40$ & 40 & $>40$ & $>40$ & $>40$ & 40 & 20 \\
\hline Ethyl acetate & 20 & 20 & 20 & 5 & 10 & 40 & 20 & 10 & 10 \\
\hline n-Butanol & $>40$ & $>40$ & $>40$ & $>40$ & 40 & $>40$ & 40 & 40 & 10 \\
\hline Aqueous & $>40$ & $>40$ & $>40$ & $>40$ & 40 & $>40$ & $>40$ & $>40$ & $>40$ \\
\hline $\begin{array}{l}\text { Isolated } \\
\text { Compound }\end{array}$ & 2 & 2 & 2 & 0.25 & $>4$ & 2 & 1 & 2 & 0.25 \\
\hline $\begin{array}{l}\text { Acrifla- } \\
\text { vin } \\
(\mathrm{mg} / \mathrm{L})\end{array}$ & 8 & 8 & 16 & 8 & 4 & 16 & 8 & $* 8$ & $* 8$ \\
\hline
\end{tabular}

* MIC of ketoconazole; MIC of 50\% aqueous methanol and Tween 80 as negative controls: $>40 \mathrm{mg} / \mathrm{mL}$ 
http://dx.doi.org/10.4314/ajtcam.v11i2.15

\section{Discussion}

The highest antioxidant activity exhibited by the ethyl acetate fraction can be attributed to the fact that it possessed the most antioxidant components or the most active structural moieties of a component which could scavenge rapidly the DPPH radical solution by reduction (Canadanovic-Brunet et al., 2005). Upon repeated column purification, the ethyl acetate fraction elaborated a thiophenolic glycoside which demonstrated a comparable $(\mathrm{p}<0.05)$ DPPH radical scavenging activity as a measure of antioxidant activity. This may be due to the presence of hydroxyl (phenolic $\mathrm{OH}$ ) and thiol groups which are free radical scavengers (Amić et al., 2003).

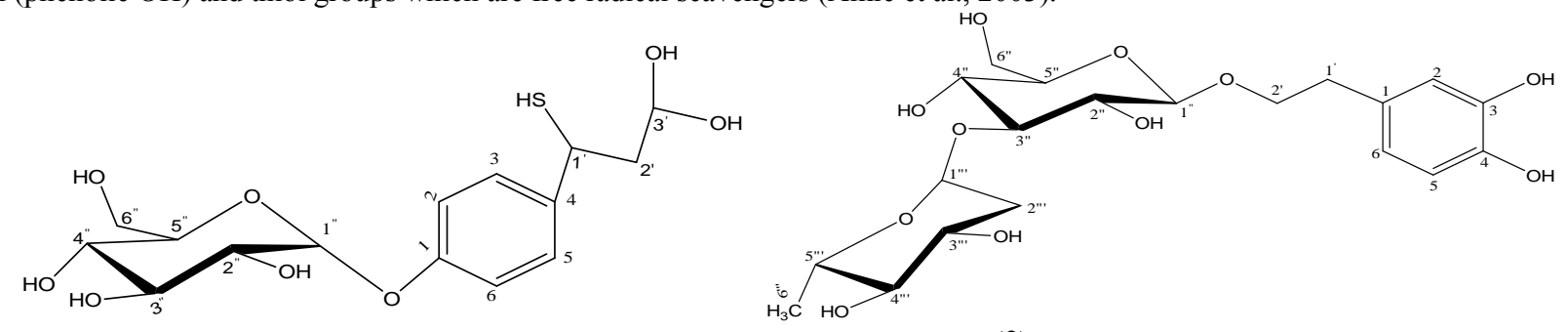

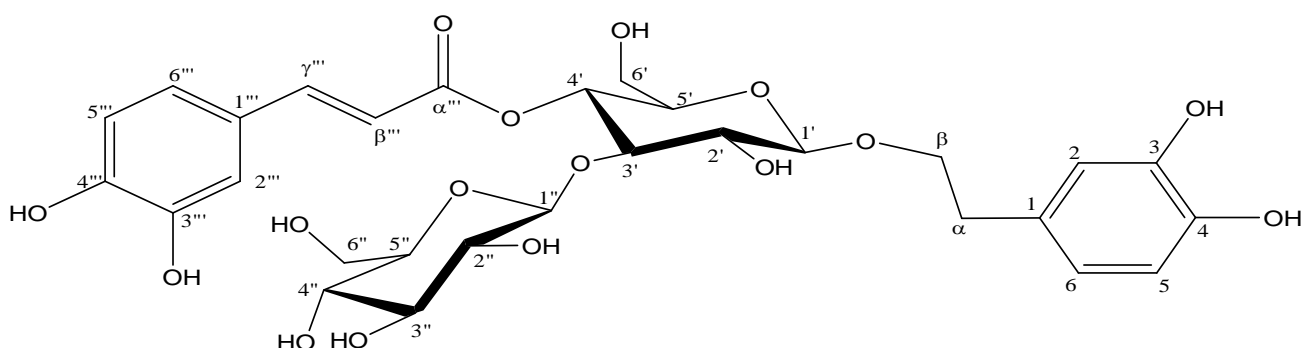

(3)

Figure 3: Structure of Compound (1) and Phenolic glycosides (2 - 3) from Literature

Table 2: Comparison of NMR Signals of Compound (1) and Reported Phenolic glycoside

\begin{tabular}{|c|c|c|c|c|}
\hline \multicolumn{3}{|c|}{ Isolated Compound (1) } & \multicolumn{2}{|c|}{$\begin{array}{l}\text { Phenolic glycoside (Kanchanapoom et al., } \\
\text { 2002) }\end{array}$} \\
\hline Position & ${ }^{1} \mathrm{H}$ NMR & ${ }^{13} \mathrm{C}$ NMR & ${ }^{1} \mathrm{H}$ NMR & ${ }^{13} \mathrm{C}$ NMR \\
\hline Aromatic ring & & & Aromatic ring & \\
\hline $\mathrm{C}-1$ & - & 154.67 & - & 131.50 \\
\hline $\mathrm{C}-2$ & $6.66(1 \mathrm{H}, d d, J=2.0 \mathrm{~Hz})$ & 115.43 & $6.66(1 \mathrm{H}, d, J=2.0 \mathrm{~Hz})$ & 117.10 \\
\hline $\mathrm{C}-3$ & $7.49(1 \mathrm{H}, d d, J=1.5 \mathrm{~Hz})$ & 131.95 & - & 144.60 \\
\hline C-4 & & 142.12 & - & 146.10 \\
\hline $\mathrm{C}-5$ & $7.49(1 \mathrm{H}, d d, J=7.0 \mathrm{~Hz})$ & 131.95 & $6.66(1 \mathrm{H}, d, J=8.3 \mathrm{~Hz})$ & 116.30 \\
\hline $\mathrm{C}-6$ & $6.66(1 \mathrm{H}, d d, J=9.0 \mathrm{~Hz})$ & 115.43 & $\begin{array}{c}6.51(1 \mathrm{H}, d d, J=8.3 \mathrm{~Hz} \\
2.0 \mathrm{~Hz})\end{array}$ & 121.30 \\
\hline $\begin{array}{l}\text { dihydroxyl-1- } \\
\text { mercaptopropyl }\end{array}$ & & 93.37 & $\alpha, \beta$-Substitution & \\
\hline $\mathrm{C}-1^{\prime}$ & $3.53(1 \mathrm{H}, m)$ & 35.00 & $3.90(1 \mathrm{H}, m)$ & 72.20 \\
\hline $\mathrm{C}-2^{\prime}$ & $2.35(b d)$ & 39.78 & $2.73(t d, J=7.0)$ & 36.50 \\
\hline $\mathrm{C}-3^{\prime}$ & $4.64(d, J=9 \mathrm{~Hz})$ & 96.44 & - & - \\
\hline Glucose & & & Glucose & \\
\hline $\mathrm{C}-1^{\prime \prime}$ & $5.67(1 \mathrm{H}, d, J=6.0 \mathrm{~Hz})$ & 100.16 & $4.32(1 \mathrm{H}, d, J=7.8 \mathrm{~Hz})$ & 104.20 \\
\hline $\mathrm{C}-2^{\prime \prime}$ & $3.23-4.28(\mathrm{~m})$ & 77.44 & $3.37(d d)$ & 76.20 \\
\hline $\mathrm{C}-3^{\prime \prime}$ & $3.23-4.28(\mathrm{~m})$ & 74.93 & $3.78(d d)$ & 81.60 \\
\hline C-4" & $3.23-4.28(\mathrm{~m})$ & 71.23 & $4.96(d d)$ & 70.40 \\
\hline C-5" & $3.23-4.28(\mathrm{~m})$ & 78.17 & $3.66(d d)$ & 76.00 \\
\hline C-6" & $3.23-4.28(\mathrm{~m})$ & 62.75 & $4.12(d d)$ & 62.40 \\
\hline
\end{tabular}

Compound 1 belongs to the class of polyphenols which are easily extractible with ethyl acetate and are characteristically anti-oxidative in their actions with considerable level of antimicrobial activity (Erol et al.,2009; Cowan, 1999) as was demonstrated by the ethyl acetate fraction and its constituent in this investigation. The susceptibility of clinical strains of methicillin resistant Staphylococcus aureus to compound $\mathbf{1}$ at MIC of $2 \mathrm{mg} / \mathrm{mL}$ is an indication that this compound may be useful in the treatment of some opportunistic infections and food borne diseases (Dupont et al., 2006). Candida albicans and C. pseudotropicalis which are causative agents of mouth infections (oral thrush/candidiasis) were also susceptible to compound $\mathbf{1}$ at reduced concentrations, hence, may justify the ethno-medicinal use of the leaves in the treatment of mouth infections.

However, the investigation was limited to the use of open column chromatography only. It would therefore be necessary to introduce faster and easily reproducible isolation techniques such as preparative system (PTLC), accelerated system (AGC and Flash chromatography), automated system (HPLC/UPLC), and the newer hyphenated systems (LC-MS/MS, LC-IR-NMR) which could assist in the isolation and characterization of novel leads from natural sources (Hostettmann and Marston, 2002). 
http://dx.doi.org/10.4314/ajtcam.v11i2.15

Isolated Compound (1)

The ${ }^{1} \mathrm{H}$ NMR spectra showed an $\mathrm{AA}^{\prime} \mathrm{BB}^{\prime}\left(\mathrm{A}_{2} \mathrm{~B}_{2}\right)$ system (para-substitution pattern) and the assignment was further confirmed by the ${ }^{13} \mathrm{C}$ NMR spectra $\left(\delta \mathrm{c} 131.95\right.$ for $\mathrm{C}-2^{\prime} / 6^{\prime}$ and $\delta \mathrm{c} 115.43$ for $\mathrm{C}-3^{\prime} / 5^{\prime}$. The effect of the less electronegative sulphur in thiol group (SH) compared to nitrogen in amino group $\left(\mathrm{NH}_{2}\right)$ and oxygen in hydroxyl group $(\mathrm{OH})$ caused a less deshielding of $\mathrm{C}-1^{\prime}$ and $\mathrm{C}-2^{\prime}$, making them to resonate at 35.00 ppm and $39.78 \mathrm{ppm}$ respectively. However, by comparison of physical data of Compound (1) with those of phenolic glycosides (Table 2) reported in literature (Arnold et al., 2002; Kanchanapoom et al., 2002) and Dictionary of Natural Products (DNP, 2012) as well as Handbook of Natural Products from Plants (Cseke et al., 2006), Compound (1) is said to be a new compound and isolated for the first time from this plant.

\section{Conclusion}

The isolated compound from the leaf of Massularia acuminata demonstrated antioxidant and antimicrobial activities and may be responsible for the activities of leaf extract and its ethyl acetate fraction, hence this may justify its ethnomedicinal use. The isolation and characterization of thiophenolic glycoside from this plant marks the first report of isolated constituent from M. acuminata and from the genus Massularia.

\section{Acknowledgments}

The authors thank Mr. T. A. Oladele of the Department of Plant Science, Faculty of Science, University of Port Harcourt, Nigeria, for plant collection and identification. Dr. Frank Schweizer of the Department of Chemistry, University of Manitoba, Winnipeg, Canada, is appreciated for making available, spectral data.

\section{References}

1. Aderinokun, G. A., Lawoyin, J. O., and Onyeaso, C. O. (1999). Effect of Two Common Nigerian Chewing sticks on Gingival Health and Oral Hygiene. Odonto-Stomatologie Tropicale 87 (12): $1274-1281$.

2. Aladesanmi, A. J., Iwalewa, E. O., Akinkunmi, E. O., Adebajo, A. C., Taiwo, B. J., Olorunmola, F. O., and Lamikanra, A. (2007). Antimicrobial and Antioxidant Activities of Some Nigerian Medicinal Plants. African Journal of Traditional Complementary and Alternative Medicines 4 (2): 173 - 184.

3. Amić, D., Davidović-Amić, D., Bešlo, D., and Trinajstić, N. (2003). Structure-Radical Scavenging Activity Relationships of Flavonoids. Croatian Chemical Acta 71 (1): 55 - 61.

4. Arnold, U. W., Zidorn, C., Ellmerer, E. P., and Stuppner, H. (2002). Iridoid and Phenolic Glycosides from Wulfenia carinthiaca. Verlag der Zeitschrift für Naturforschung 57C: $969-975$.

5. Burkill, H. M. (1997). Useful Plants of West Tropical Africa, Vol. 4. Royal Botanic Garden, Kew. UK.

6. Canadanovic-Brunet, J. M., Djilas, S. M., and Cetkovic, G. S. (2005). Free-radical Scavenging Activity of Wormwood (Artemisia absinthium) Extracts. Journal of the Science of Food and Agriculture 85: 265 - 272.

7. Clinical Laboratory Standard Institute (CLSI) (2007). Document M2-A9 and M7-A7. Performance Standards for Antimicrobial Susceptibility Testing; Seventh Information Supplement. CLSI, 940 West Valley Road, Suite 1400, Wayne, Pennsylvania, USA. 19087 - 19098.

8. Cowan, M. M. (1999). Plant products as antimicrobial agents. Clinical Microbiology Review 12 (4): $564-582$.

9. Cseke, L. J., Kirakosyan, A., Kaufman, P. B., Warber, S. L., Duke, J. A., and Brielmann, H. L. (2006). Natural Products from Plants. Second Edition.Taylor and Francis Group (CRC Press), Boca Raton, FL 33487 - 2742.

10. DNP (2012). Dictionary of Natural Products: A Compilation of the National Institute for Occupational Safety and Health Services. Department of Health and Human Services, USA. 1 - 210.

11. Dupont, S., Caffin, N., Bhandari, B., and Dykes, G. A. (2006). In vitro Antibacterial Activity of Australian Native Herb Extracts Against Food-related Bacteria. Food Control 17: 929 - 932.

12. Erol, N. T., Sari, F., Polat, G., and Velioglu, Y. S. (2009). Antioxidant and Antibacterial Activities of Various Extracts and Fractions of Fresh Tea Leaves and Green Tea. Tarim Bilimleri Dergisi 15 (4): 371 - 378.

13. Gülçin, I., Alici, H. A., and Cesur, M. (2005). Determination of In vitro and Radical Scavenging Activities of Propofol. Chemica Pharmaceutica Bulletin 53: 281 - 285.

14. Halliwell, B., (2007). Biochemistry of Oxidative Stress. Biochemical Society Transaction 35 (5): 1147 - 1150.

15. Hostettmann, K. and Marston, A. (2002). Twenty Years of Research into Medicinal Plants: Results and Perspectives. Phytochemistry Reviews 1: $275-285$.

16. Kanchanapoom, T., Kasai, R., and Yamasaki, K. (2002). Phenolic Glycosides from Barnettia kerrii. Phytochemistry 59: 565 - 570.

17. Li, W. J., Cheng, X. L., Liu, J., Lin, R. C., Wang, G. L., Du, S. S., and Liu, Z. L. (2012). Phenolic Compounds and Antioxidant Activities of Liriope muscari. Molecules 17: 1797 - 1808.

18. Sanchez-Moreno, C., Larrauri, J. A., and Saura-Calixto, F. A. (1998). Procedure to Measure the Antiradical Efficiency of Polyphenols. Journal of Science Food and Agriculture 76: 270 - 276.

19. Taiwo, O., Xu, H.X., and Lee, S. F. (1999). Antibacterial Activities of Extracts from Nigerian Chewing Sticks. Phytotherapy Research 13: $675-679$.

20. Turkoglu, A., Kivrak, I., Mercan, N., Duru, M. E., Gezer, K., and Turkoglu, H. (2006). Antioxidant and Antimicrobial Activities of Morchella conica Pers. African Journal of Biotechnology 5 (11): 1146 - 1150. 